\title{
Identification of Genes Regulated by Memantine and MK-80 I in Adult Rat Brain by cDNA Microarray Analysis
}

\author{
Markéta Marvanová', Merja Lakso' and Garry Wong*,' \\ 'Al Virtanen Institute for Molecular Sciences, Department of Neurobiology, Laboratory of Functional Genomics and Bioinformatics, University of \\ Kuopio, Kuopio, Finland
}

\begin{abstract}
In this study, we monitored gene expression profiles using cDNA microarrays after an acute systemic administration of the high affinity N-methyl-D-aspartate (NMDA) uncompetitive antagonist MK-80I (I mg/kg; 4h), and the clinically used moderate affinity antagonist memantine $(25 \mathrm{mg} / \mathrm{kg} ; 4 \mathrm{~h})$ in adult rat brains. From a microarray containing 1090 known genes, 13 genes were regulated by both treatments of which 12 were upregulated and one was downregulated. In addition, 28 and 34 genes were regulated $(\geqslant 1.5$ - or $\leqslant 0.67-$ fold change) by either memantine or MK-80 I, respectively. Genes commonly regulated by both treatments and not previously reported were confirmed by in situ hybridization (ISH) and include regenerating liver inhibitory factor-I (RL/F-I), GDP-dissociation inhibitor I (GDI-I), neural visinin $\mathrm{Ca}^{2+}$-binding protein 2 (NVP-2), neuromedin $\mathrm{B}$ receptor, and $\mathrm{Na}^{+} / \mathrm{K}^{+}$transporting ATPase $2 \beta$. ISH with memantine $(5-50 \mathrm{mg} / \mathrm{kg})$ revealed regulation of these genes in other cortical and hippocampal regions. RL/F-I induction occurred at I $\mathrm{h}$ and returned to basal levels by $8 \mathrm{~h}$, consistent with the profile of an immediate early gene. Western blot analysis showed increases $(\sim 30-65 \%)$ in GDI-I protein present in both cytosolic and membrane fractions that were significant in the 84-kDa Rab bound form, suggesting that memantine influences Ras-like GTPase function. Genes regulated by a $5 \mathrm{mg} / \mathrm{kg}$ dose of memantine might be important in its therapeutic effects. These findings increase the number of known, differentially altered genes after treatment of uncompetitive NMDA receptor antagonists and suggest broader actions of these agents than previously realized.

Neuropsychopharmacology (2004) 29, 1070-1079, advance online publication, 18 February 2004; doi: 10.1038/sj.npp. I300398
\end{abstract}

Keywords: microarray; gene expression; in situ hybridization; glutamate NMDA receptors; memantine; MK-80 I

\section{INTRODUCTION}

Glutamate receptor blockers with selective action on $\mathrm{N}$-methyl-D-aspartate (NMDA) receptors have wide therapeutic potential in a variety of central nervous system (CNS) disorders ranging from the acute neurodegeneration (eg stroke and trauma), chronic neurodegeneration (eg Parkinson's disease (PD), Alzheimer's disease (AD), and Huntington's disease (HD) (Danysz et al, 1995; Parsons et al, 1998; Krystal et al, 1999), to symptomatic treatment (eg epilepsy, PD, drug dependence, depression, anxiety, and chronic pain) (Meldrum, 1986; Danysz et al, 1995; Krystal et al, 1999; Skolnick, 1999).

In these conditions, an excessive release of glutamate is thought to play a major role in triggering neuronal death via

\footnotetext{
*Correspondence: Dr Garry Wong, Al Virtanen Institute, Functional Genomics and Bioinformatics Laboratory, Department of Neurobiology, University of Kuopio, PO Box 1627, 7021। Kuopio, Finland, Tel: + 35817 162108, Fax: + 35817 163030,

E-mail: Garry.Wong@uku.fi

Received 09 June 2003; revised 19 November 2003; accepted II December 2003

Online publication: 4 January 2003 at http://www.acnp.org/citations/ Npp0 I 050403257/default.pdf
}

NMDA receptors (Choi, 1988; Danysz et al, 1995; Parsons et al, 1998). NMDA receptor channel blockers represent one group of pharmacologically active agents able to antagonize NMDA receptor activation by acting directly on the phencyclidine recognition site within the channel. Since these agents act in a 'use-dependent' manner, only blocking the channel in the open state (Foster and Wong, 1987; Huettner and Bean, 1988), they have been termed uncompetitive NMDA receptor antagonists.

Dizocilpine maleate (MK-801) is a prototypical NMDAreceptor channel blocker with a high affinity to the ion channel (Wong et al, 1986). However, high affinity NMDA receptor channel blockers have been observed to elicit psychotomimetic properties in humans (Krystal et al, 1999), and thus have been useful only experimentally in vitro and in vivo. In contrast, memantine (1-amino-3,5-dimethyladamantane), an uncompetitive NMDA receptor antagonist of moderate affinity to the receptor-associated ion-channel, exhibits fast blocking and unblocking kinetics, high voltage dependency (Kornhuber et al, 1991; Parsons et al, 1993), and is well tolerated at clinical doses (Parsons et al, 1999). Memantine is suggested as a neuroprotective agent for the treatment of several dementias, particularly AD (Görtelmeyer and Erbler, 1992; Muller et al, 1995; Parsons et al, 
1999). Moreover, memantine and acetylcholinesterase inhibitors are currently the only agents widely used to improve cognition and daily activities in patients with $\mathrm{AD}$ (Kilpatrick and Tilbrook, 2002; Winblad et al, 2002). Memantine has been approved for clinical use in Europe and is currently undergoing clinical trials in the United States (Kilpatrick and Tilbrook, 2002). Thus, information concerning the molecular pharmacology of memantine is important to understand its actions and to anticipate potential adverse effects.

We sought to characterize the genes with altered expression in adult rat brain after MK-801 and memantine treatment in order to better understand the multiple actions of NMDA/glutamate antagonists. cDNA microarray-based hybridization techniques offer a high throughput platform that allows for rapid and cost-effective screens to detect effects of pharmacological agents (Schena et al, 1995; Grunblatt et al, 2001; Ueda et al, 2002). Here, we utilized a microarray containing $1090 \mathrm{cDNA}$ fragments and in situ hybridization (ISH) to determine the gene expression alterations in response to treatment with uncompetitive NMDA receptor antagonists in rat limbic cortex. We were able to identify several genes with altered expression in response to MK-801 and memantine treatment. In addition to already known and identified genes involved in either pharmacological or toxicological effects, the study also uncovered a number of new gene/treatment correlations. Characterization of these genes may lead to better understanding of the molecular pharmacology of uncompetitive NMDA receptor antagonists. More importantly, some of these genes may constitute novel targets for new therapeutic use.

\section{MATERIALS AND METHODS}

Male Wistar rats (initial weight 250-280 g, National Laboratory Animal Center, University of Kuopio, Kuopio, Finland) were kept under standardized temperature, humidity, and lighting conditions (12-h light/dark cycles) with free access to water and food. All attempts were made to minimize pain and discomfort of the experimental animals. All animal treatments were approved by the Experimental Animal Committee of the University of Kuopio, and they have been carried out in accordance with the guidelines issued by the Society for Neuroscience.

Doses and duration of the treatment with uncompetitive NMDA receptor antagonists, MK-801 and memantine, used in this study were based on the previous studies. Memantine intraperitoneally (i.p.) dose $25 \mathrm{mg} / \mathrm{kg}$ ( $4 \mathrm{~h}$ ) was shown to increase significantly BDNF mRNA levels in the rat brain (Marvanová et al, 2001) and produce plasma levels reaching $\sim 6.5 \mu \mathrm{M}$ concentrations, which are still within the range specific to NMDA receptor affinity (Kornhuber et al, 1994). Moreover the neuroprotective dose of memantine in rats has been shown to be $10-30 \mathrm{mg} / \mathrm{kg}$ in acute indications (Wenk et al, 1994). A $5 \mathrm{mg} / \mathrm{kg}$ i.p. dose of memantine in rats produces plasma levels of $\sim 1 \mu \mathrm{M}$ that can be considered therapeutically relevant (Parsons et al, 1999). It has been suggested that neuroprotective doses of MK-801 $(0.3-0.8 \mathrm{mg} / \mathrm{kg}$; i.p.) block NMDA receptors in the brain, and these doses produce plasma concentrations within the range of NMDA receptor affinity (Gill et al, 1991; Massieu et al, 1993).

Rats were injected i.p. with saline (control group of animals) or with $5,10,25$, and $50 \mathrm{mg} / \mathrm{kg}$ of memantine $\mathrm{HCl}$, and killed $1-48 \mathrm{~h}$ afterwards as indicated. In all, $1 \mathrm{mg} / \mathrm{kg}$ MK-801 (dizocilpine maleate) (RBI, Natick, MA, USA) was applied to rats that were killed $4 \mathrm{~h}$ afterwards.

The rats were narcotized with $\mathrm{CO}_{2}$ before decapitation. Brains were rapidly removed and posterior cingulate and anterior retrosplenial cortices were rapidly and carefully dissected and immediately stored on dry ice to be processed for RNA isolation. Brains for ISH histochemistry were rapidly removed and rinsed in $\mathrm{PBS}$ ( $\mathrm{pH} 7.5$ ), placed on dry ice, and stored at $-80^{\circ} \mathrm{C}$. Coronal brain sections $(14 \mu \mathrm{m})$ were cut on a Leica CM 3000 cryostat and thaw-mounted onto SuperFrost/Plus (Menzel-Glaeser, Germany) slides. Brain sections from saline (control) and treated rats were comounted onto the same slides and fixed in $4 \%$ paraformaldehyde solution, and stored in $95 \%$ ethanol at $4^{\circ} \mathrm{C}$ until use.

\section{cDNA Array}

Rat 1.0 Atlas Glass Microarrays for dual color analyses (Clontech Laboratories, Palo Alto, CA, USA) were utilized in this study. The array contains 86 controls and 1090 wellcharacterized transcripts with assigned function and a broad functional range class. Each gene is represented by 'long oligo', single-stranded cDNA fragments of around 80 bases that lack repetitive elements and have minimal homology with other genes on the array. The full gene list can be found at http://www.uku.fi/aivi/supplementary_in formation.htm.

\section{RNA Extraction, Probe Synthesis, and Hybridization}

Total RNA was isolated from frozen tissue using Trizol reagent (Gibco BRL, MD, USA) according to the manufacturer's recommended protocol. The total RNA was then DNase I treated (Ambion, Inc., Texas, USA). The integrity of RNA was verified with a $1 \%$ agarose-formaldehyde minigel and concentrations were obtained by measuring absorbance at $260 \mathrm{~nm}$. Fluorescently labeled probes were synthesized from total RNA $(20 \mu \mathrm{g})$ by reverse transcription and indirect incorporation of fluorescent dye ( $\mathrm{Cy} 3$ and $\mathrm{Cy} 5)$ according to the manufacturer's protocol. Following hybridization $\left(42^{\circ} \mathrm{C}\right.$, for $\left.16 \mathrm{~h}\right)$ with fluorescently labeled cDNAs in hybridization chambers, all arrays were washed and then scanned (ScanArray 5000, GSI Lumonics, Inc., Billerica, MA, USA).

\section{Gene Expression Data Analysis}

Raw scanned images of $\mathrm{Cy} 3$ and $\mathrm{Cy} 5$ fluorescence were processed and the signal from each spot was then quantified using QuantArray analysis software (GSI Lumonics, Inc.). The local background was subtracted from the fluorescent values of each spot to obtain an intensity value. For each individual treatment, duplicate microarrays were hybridized with rat brain mRNA samples obtained from two rat individuals. In this hybridization study a 'swapped dyes' design was used. On one microarray, the treatment sample 
was labeled with Cy5, and control was labeled with Cy3. The dyes were then switched where the treatment sample was labeled with $\mathrm{Cy} 3$ and control was labeled with $\mathrm{Cy} 5$. In principle, the ratios of treatment (Cy-5)/control (Cy-3) and treatment (Cy-3)/control (Cy-5) should be approximately equal. In order to account for any differential incorporation of the fluorescent labels and differences in scanning parameters, the signal intensities for $\mathrm{Cy} 3$ and Cy5 were globally normalized and the expression ratios between experimental and control samples were determined. Genes were upregulated if they displayed a ratio $\geqslant 1.5$ and downregulated if the ratio was $\leqslant 0.67$ in both replicate dye swap experiments. The cut-off value for gene induction or suppression were chosen based on observed gene expression data, and previously reported microarray profiling studies of brain regions, which showed that the magnitude of gene expression differences is often less than two-fold in brain tissue (Mirnics et al, 2000). The analyzed expression data sets of memantine and MK-801 experiments are located on the publicaly available website (http://www.uku.fi/aivi/supplementary_informa tion.htm).

\section{In situ Hybridization}

ISH was performed as described previously (Marvanová et al, 2001). Briefly, the antisense oligonucleotides of rat RL/ IF-1 (5'-GTAGGGCAACTCATCTTCCGTGAATTCTGACT CCG-3'), rat GDI-1 (5'-GGAGATCATGCACACATAGATGT CTGGCTTCCTGT-3'), rat PAK-1 (5'-CTCTGCACACAGC TGCTATCTGGCCTTCATCCATA- $\left.3^{\prime}\right)$, rat SHPS-1 (5'-CTG TTTGATTCGGAGGAGGTAGAGGGCAGCCATCA-3 ${ }^{\prime}$ ), rat NVP-2 (5'-CACCAGCCCTACTTCTGCATGTCACATTGC AACAG-3'), rat GRP78 (5'-GGCCTGAGAATAGCGAGCAG CAACGTCTCGAGCTT- $\left.3^{\prime}\right)$, rat neuromedin B receptor $\left(5^{\prime}\right.$ AACTGCTGTTATCCGAGCTACCGATGCGTGCTACT-3'), rat ARF-3 (5'-GAGCTCATCCTCCGCCAGCATCCTCATCAGC TCTT- $\left.3^{\prime}\right)$, rat prostaglandin E2 receptor $\left(5^{\prime}\right.$-CTGCATGC GAATAAGGTTGAGGATCACACTGATG- $3^{\prime}$ ), rat calcium channel $\beta\left(5^{\prime}\right.$-TTCACTCTGTACCTCAGCCAGGCTGGAGC GAGTGT-3'), rat HSP90 $\beta$ ( $5^{\prime}$-TCTTCATCAATGCCCAGG CCTAGTTTAATCATGCG3 ${ }^{\prime}$ ), rat dopamine D4 receptor ( $3^{\prime}$-TCGGCAGCCGCCAGGCTCACGATGAAGTAGTTGGT- ${ }^{\prime}$ ), rat c-fos (5'-GCAGCGGGAGGATGACGCCTCGTAGTCCG CGTTGAAACCCGAGAA-3 ${ }^{\prime}$ ), and rat FGF-2 (5'-AGTGTC TAAAGAGAGTCAGCTCTTAGCAGACATTG- $3^{\prime}$ ), rat K ${ }^{+} / \mathrm{Na}^{+}$ transporting ATPase $2 \beta$ ( $5^{\prime}$-TTTAGCTGGGTCCGGTTGAA CTGGCAGGCACGTT- $3^{\prime}$ ), rat F-spondin (5'-ACACTTCT CCGCCTGCTCCAGATCCTCATTACAGT- $3^{\prime}$ ) mRNAs were $3^{\prime}$ end-labeled to a specific activity of $1-2 \times 10^{7} \mathrm{cpm} / \mathrm{pmol}$ using terminal deoxynucleotidyl transferase (MBI Fermentas, Vilnus, Lithuania) and a 30:1 molar ratio of $\alpha-\left[{ }^{33} \mathrm{P}\right]-$ dATP $(2000 \mathrm{Ci} / \mathrm{mmol}$, New England Nuclear, Boston, MA) to probe. Hybridization was performed for $21 \mathrm{~h}$ at $42^{\circ} \mathrm{C}$ on paraformaldehyde postfixed sections in the presence of 1$3 \times 10^{3} \mathrm{cpm} / \mu \mathrm{l}$ of labeled probe in buffer containing $50 \%$ formamide, $4 \times$ standard saline citrate (SSC) $(1 \times$ SSC: $150 \mathrm{mM} \mathrm{NaCl}, 15 \mathrm{mM}$ sodium citrate), and $10 \%$ dextran sulfate. After incubation, the sections were washed and opposed onto Hyperfilm- $\beta$ max films (Amersham Life Sciences, Inc., Buckinghamshire, England) for 5 days to 3 weeks and developed for $5 \mathrm{~min}$ in D-19 (Kodak, France).
Nonspecific hybridization was determined by adding 100 fold excess of unlabeled oligonucleotide probe to the hybridization buffer. Nonspecific hybridization was not significantly above the background.

\section{Immunoblotting}

Tissues from posterior cingulate and anterior retrosplenial cortices were rapidly dissected and well homogenized in $1 \mathrm{ml}$ of lysis buffer $(50 \mathrm{mM}$ Hepes, $\mathrm{pH} 7.5,150 \mathrm{mM} \mathrm{NaCl}$, $2.5 \mathrm{mM} \mathrm{MgCl}_{2}$, Protease inhibitors and $0.1 \mathrm{mM} \mathrm{GDP}$ ). The homogenate was spun for $10 \mathrm{~min}$ at $600 \mathrm{~g}$ at $4^{\circ} \mathrm{C}$ to remove nuclear fractions and intact cells. The supernatant was transferred to SW 40 swinging bucket rotor tubes and centrifuged at $100000 \mathrm{~g}$ for $30 \mathrm{~min}$ at $4{ }^{\circ} \mathrm{C}$. After centrifugation, the supernatant containing cytosolic fraction was removed to a separate tube and the obtained pellet containing membrane protein was resuspended in $250 \mu \mathrm{l}$ of lysis buffer. All protein fractions were stored in $-80^{\circ} \mathrm{C}$ until use. After measuring protein concentrations (Dc Protein Assay, BioRad, Richmond, CA, USA), samples consisting of equal amounts of protein $(20 \mu \mathrm{g})$ were subjected to $7.5 \%$ sodium dodecyl sulfate-polyacrylamide gel electrophoresis (SDS-PAGE). Proteins were transferred to nitrocellulose membranes (Protran, Schleicher \& Schuell, Jeene, $\mathrm{NH}$ ) and then blocked with $3 \%$ bovine serum albumin (BSA) in TBS containing $0.1 \%$ Tween 20 (TBS-T). Immunoblotting was carried out with the rabbit GDI-1 (GDP-dissociation inhibitor 1) (Amersham Life Sciences, Inc.) and anti-actin (c-11, goat polyclonal IgG) (Santa Cruz Biotechnology, Santa Cruz, CA, USA) primary antibodies using $1: 1000$ dilutions at $4{ }^{\circ} \mathrm{C}$ overnight. Filters were rinsed in water twice and in PBS containing 0.05\% Tween twice. Bound immunoglobulins were detected with anti-rabbit (Amersham) or anti-goat (Santa Cruz Biotechnology) horseradish peroxidase-conjugated secondary antibodies at $1: 1000$ dilution for $1 \mathrm{~h}$ at room temperature, rinsed, and followed by chemiluminescence detection using luminol (Sigma-Aldrich, Helsinki, Finland) as the substrate. Signals were exposed to films for 1-10 min.

\section{Data Analysis}

Optical densities from immunoblot and ISH films were quantified by a video-based image analysis system (MCID M4, Imaging Research, Inc., St Catharines, Ontario, Canada). The anatomical brain regions were determined according to Paxinos and Watson (1986). For ISH autoradiograms, ${ }^{14} \mathrm{C}$-microscales were exposed simultaneously to convert optical densities to nCi/g statistical analysis was performed with ANOVA followed by Dunnett's post hoc test.

\section{RESULTS}

\section{Expression Array Data Analysis}

To examine the molecular mechanisms contributing to the effect of MK-801 and memantine, mRNA expression was profiled using Clontech Rat 1.0 glass arrays containing 1090 genes of known function. Expression levels and profiles of genes were obtained after saline and MK-801 $(1 \mathrm{mg} / \mathrm{kg} ; 4 \mathrm{~h})$, 
or saline and memantine $(25 \mathrm{mg} / \mathrm{kg} ; 4 \mathrm{~h})$ systemic administrations in rat posterior cingulate and anterior retrosplenial cortices. Duplicate microarrays were hybridized and the ratios (treated $v s$ control) were calculated for each individual array. Analysis of both arrays from each treatment revealed that 28 genes were differentially altered after memantine administration (Tables 1 and 3; Figures 1 and 2) while 34 genes were differentially altered after MK-801 administration (Tables 2 and 3; Figures 1 and 2). A total of 13 genes were regulated by both treatments of which 12 were upregulated and one was downregulated (Table 3).

\section{ISH Analysis of Candidate Genes}

ISH was used to independently verify the results from previous microarray analyses as well as to determine brain expression distribution, dose response, and time course. ISH from five to six rat brains treated with MK-801 (i.p.; $1 \mathrm{mg} / \mathrm{kg} ; 4 \mathrm{~h}$ ) or memantine (i.p.; $5-25 \mathrm{mg} / \mathrm{kg} ; 4 \mathrm{~h}$ ) was performed for several up- or downregulated candidate genes. Candidate genes selected for ISH analysis were based on groups of genes regulated by both treatments, by only memantine, or by only MK- 801 .

\section{ISH Analysis of Candidate Genes after Memantine Treatment}

From the microarray analysis, 28 candidate genes were identified of which five were previously confirmed by the literature, and 10 were confirmed by ISH with one false positive (Tables 1 and 3). Moreover, we confirmed the regulation of memantine selectively altered genes: PAK-1, SHPS-1, calcium channel $\beta$, and F-spondin. Additionally, one false negative was observed (c-fos). Quantification of these results can be found as supplemental material (http:// www.uku.fi/aivi/supplementary_information.htm).

Regenerating liver inhibitory factor-1 (RL/IF-1), GDI-1, SHPS-1, PAK-1, and neural visinin $\mathrm{Ca}^{2+}$-binding protein 2 (NVP-2) were further subjected to study memantineinduced dose response and time course. mRNA levels of RL/IF-1 gene was significantly increased in all investigated brain regions $(32 \pm 3.4 \%)$ (Figures $1 \mathrm{a}$ and $2 \mathrm{a}$ ). Gene expression levels of GDI-1 were significantly increased in retrosplenial cortex with an increase of $25 \pm 4.4 \%$ and in all studied hippocampal regions with an increase of $29 \pm 4.4 \%$ (Figures $1 \mathrm{~b}$ and 2a). NVP-2 mRNA level was decreased in retrosplenial and temporal cortices $(86 \pm 1.0 \%)$, and $22 \pm 5.2 \%$ increased in DG (Figures 1c and 2a). Moreover, the gene SHPS- 1 was significantly increased $14 \pm 1.0 \%$ in retrosplenial and temporal cortices, and $26 \pm 6.5 \%$ in DG (Table 4). Furthermore, gene expression of PAK-1 gene was induced with $28 \pm 4.4 \%$ increase in studied cortical regions, and $31 \pm 2.4 \%$ in hippocampal DG, CA1 and CA3 regions (Table 4).

A dose response to memantine $(5-50 \mathrm{mg} / \mathrm{kg})$ was performed with the RL/IF-1, GDI-1, SHPS-1, and PAK-1 genes (Table 4). The lowest dose of memantine used, $5 \mathrm{mg} /$ $\mathrm{kg}$, which can be considered clinically relevant, was able to increase significantly mRNA levels of GDI-1 and PAK-1 in several regions of rat hippocampus. The second lowest dose of memantine (i.p.; $10 \mathrm{mg} / \mathrm{kg} ; 4 \mathrm{~h}$ ) was able to increase
Table I Profiling of Genes Altered by Memantine Administration (i.p.; $25 \mathrm{mg} / \mathrm{kg} ; 4 \mathrm{~h}$ ) in Rat Limbic Cortex

\begin{tabular}{|c|c|c|c|c|c|}
\hline $\begin{array}{l}\text { Representative } \\
\text { gene name }\end{array}$ & GenBank\# & Swissprot\# & Mem\#I & Mem\#2 & Conf. \\
\hline \multicolumn{6}{|c|}{ Transcription activators/repressors } \\
\hline $\mathrm{RL} / \mathrm{IF}-\mathrm{I}^{\mathrm{a}}$ & $\times 63594$ & Q63746 & 1.86 & 1.72 & + \\
\hline \multicolumn{6}{|c|}{ Growth factors/receptors } \\
\hline $\operatorname{TrkB}^{\mathrm{a}}$ & M5529I & Q63604 & 1.58 & 1.64 & $L$ \\
\hline \multicolumn{6}{|c|}{ Chaperones/heat shock proteins } \\
\hline $\mathrm{HSP70}{ }^{\mathrm{a}}$ & $Z 27118$ & Q63718 & 1.80 & 2.00 & $\mathrm{~L}$ \\
\hline HSP9O $\beta$ & S45392 & P34058 & 0.65 & 0.64 & + \\
\hline GRP78 ${ }^{a}$ & MI4050 & P0676I & 1.72 & 1.97 & - \\
\hline \multicolumn{6}{|c|}{ Vesicle- and synaptic-related genes } \\
\hline$G D I-I^{a}$ & U07952 & P50398 & 1.73 & 1.64 & + \\
\hline$N V P-2^{a}$ & $D|3| 25$ & P35332 & 0.63 & 0.52 & + \\
\hline Syntaxin IA & M95734 & P3285। & 1.55 & 1.53 & \\
\hline \multicolumn{6}{|c|}{ Neurotransmitter/hormone receptor } \\
\hline NMDAR2B ${ }^{a}$ & M91562 & Q00960 & 1.57 & 1.61 & L \\
\hline $\begin{array}{l}\text { Retinoid } x \alpha \\
\text { receptors }\end{array}$ & L06482 & Q05343 & 1.56 & 1.61 & \\
\hline \multicolumn{6}{|c|}{ G-protein-coupled receptors } \\
\hline $\begin{array}{l}\text { Neuromedin B } \\
\text { receptor }^{\mathrm{a}}\end{array}$ & U37058 & P24053 & 1.76 & 1.59 & + \\
\hline \multicolumn{6}{|l|}{ Neuropeptides } \\
\hline$N P Y^{a}$ & M20373 & P07808 & 1.52 & 1.64 & $\mathrm{~L}$ \\
\hline $\mathrm{CRF}^{\mathrm{a}}$ & M54987 & P0। 143 & 1.62 & 1.53 & $L$ \\
\hline \multicolumn{6}{|c|}{ Osmotic balance regulators } \\
\hline SCNB2 & U37026 & P54900 & 1.55 & 1.51 & \\
\hline CACNAI & M59786 & P22002 & 1.62 & 1.50 & \\
\hline $\begin{array}{l}\qquad \mathrm{Na}^{+} / \mathrm{K}^{+} \\
\text {transporting } \\
\text { ATPase } 2 \beta^{\mathrm{a}}\end{array}$ & j04629 & PI3638 & 1.69 & 1.52 & + \\
\hline $\begin{array}{l}\mathrm{Ca}^{2+} \\
\text { transporting } \\
\text { ATPase-isoform 2 }\end{array}$ & 03754 & PII506 & 1.67 & 1.52 & \\
\hline $\begin{array}{l}\text { Calcium } \\
\text { channel } \beta\end{array}$ & $\times 61394$ & P54283 & 1.56 & 1.69 & + \\
\hline \multicolumn{6}{|c|}{ Complex lipid/xenobiotic metabolizing enzymes } \\
\hline CYP4A8 & M37828 & P24464 & 1.69 & 1.64 & \\
\hline CYP2CII & P08683 & Q64554 & 1.57 & 1.76 & \\
\hline GST7-7 & $\times 02904$ & P04906 & 1.55 & 1.54 & \\
\hline \multicolumn{6}{|l|}{ Intracellular kinases } \\
\hline PAK-I & U23443 & P35465 & 1.91 & 1.91 & + \\
\hline \multicolumn{6}{|c|}{ Intracellular phosphatases } \\
\hline $\begin{array}{l}\text { Protein } \\
\text { phosphatase }\end{array}$ & M2359I & PII082 & 1.54 & 1.59 & \\
\hline $2 A^{a}$ & & & & Table Contir & ued ... \\
\hline
\end{tabular}


Table I (Continued)

Representative

gene name GenBank\# Swissprot\# Mem\#I Mem\#2 Conf.

Glucose metabolism and regulation

$\begin{array}{lllll}\begin{array}{l}\text { Pyruvate } \\ \text { dehydrogenase }\end{array} & \text { L22294 } & \text { Q63065 } & 1.54 & 1.54 \\ \text { kinase } & & & \\ \end{array}$

Miscellaneous group

$\begin{array}{lllll}\text { SHPS-I } & \text { D85I83 } & \text { BAAI2734 } & 1.55 & 1.51 \\ \text { F-spondin } & \text { M88469 } & \text { P35446 } & 1.88 & 1.66 \\ \text { CPR } & \text { MI25I6 } & \text { P00388 } & 0.64 & 0.62 \\ \text { Antigen } & \text { X57523 } & \text { P36370 } & 0.66 & 0.65 \\ \text { peptide } & & & & \\ \text { transporter I } & & & & \end{array}$

Expression ratios shown represent the ratio obtained with each of microarray duplicate and indicate normalized, non-log 2 -transformed ratios of memantineover saline-treated animals.

${ }^{a} G e n e$ also regulated by MK-80I. Symbols for confirmation (Conf.): + , confirmed by ISH; -, false positive; L, confirmation by literature. PAK-I, $\alpha$ serine/ threonine kinase; HSP70, heat shock protein 70; GRP-78, $78 \mathrm{kDa}$ glucose regulated protein precursor, RLIF-I, regenerating liver inhibitory factor I; GDI-I, GDP-dissociation inhibitor I; CYP2CI I, cytochrome P450 IICI I; CYP4A8, cytochrome P450 IVA8; trkB, tyrosine kinase receptor; NMDAR2B, N-methyl-Daspartate receptor $2 \mathrm{~B}$ subunit; NPY, neuropeptide Y; CRF, corticotropinreleasing factor; CACNAI, voltage-dependent P/Q-type calcium channel $\alpha$-IA subunit; GST7-7, glutathione S-transferase P; SHPS-I, receptor-like protein with SH2-binding site; SCNB2, sodium channel $\beta 2$ subunit; $H S P 90 \beta$, heat shock protein $90 \beta$, CPR, NADPH-cytochrome P450 reductase; NVP-2, neural visinin $\mathrm{Ca}^{2+}$-binding protein 2
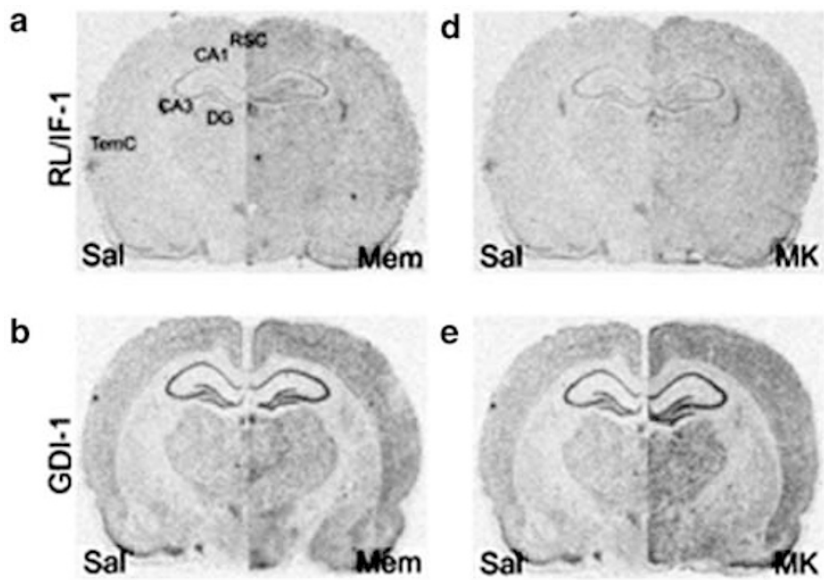

C
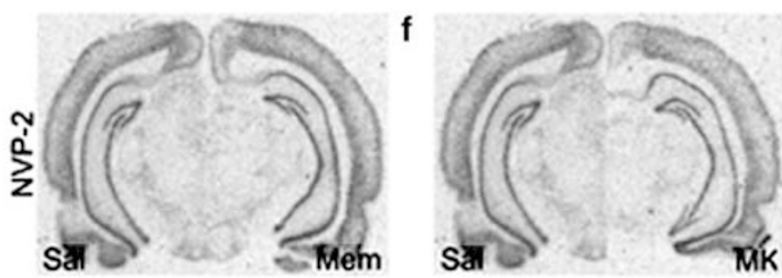

Figure I Acute systemic administration of memantine and MK-80 I regulated gene expression of candidate genes in rat brain. Representative autoradiograms from ISH showing differential gene expression of RL/IF- I (a, d), GDI-I (b, e), and NVP-2 (c, f) after saline (Sal), memantine (Mem), and MK-80I (MK) treatments. Retrosplenial cortex (RSC), temporal cortex (TemC), dentate gyrus (DG), hippocampal regions (CAI and CA3).
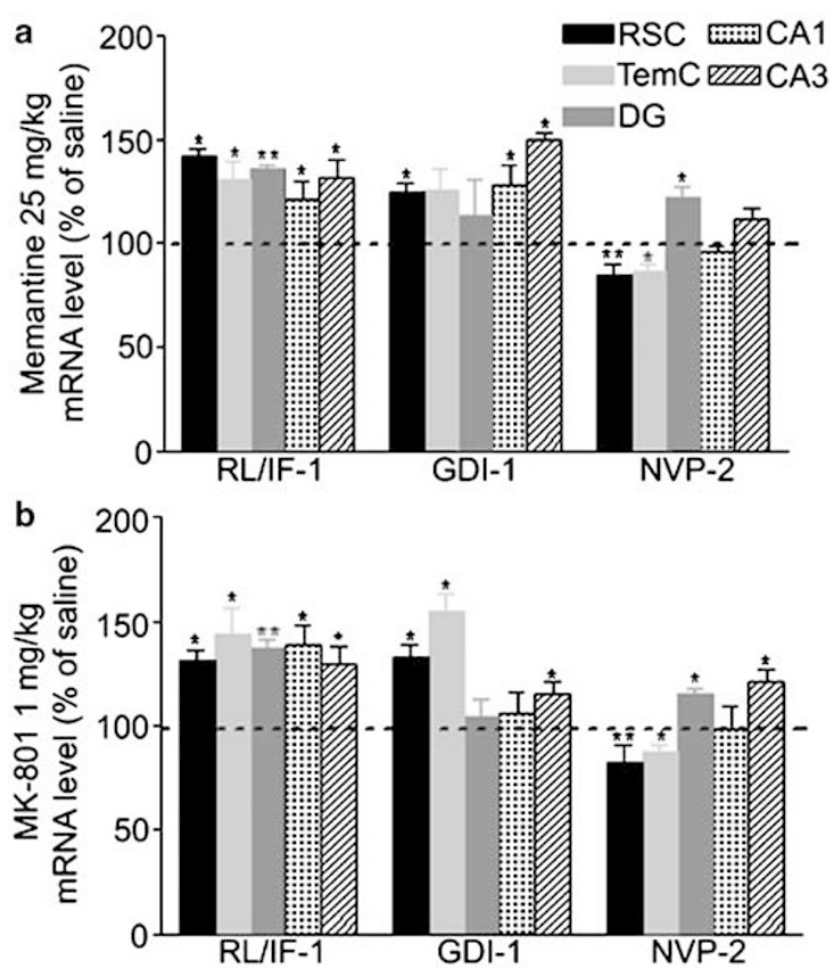

Figure 2 The effect of acute memantine $(25 \mathrm{mg} / \mathrm{kg}$ ) and MK-80 I (I mg/ $\mathrm{kg}$ ) systemic administration in rat brain. The rats were i.p. injected with $25 \mathrm{mg} / \mathrm{kg}$ of memantine or I mg/ $/ \mathrm{kg}$ of MK-80 I and killed $4 \mathrm{~h}$ later. In all, $14 \mu \mathrm{m}$ coronal brain sections were hybridized by radioactive ISH with oligonucleotide probes. Exposure time for autoradiograms was I-3 weeks. Histograms of the region-expression levels are shown for memantine (a) and for MK-80I (b) acute administration. Data are mean \pm SEM obtained from five to six brains in each group. Significant differences between saline and treated rats are indicated: * $p<0.05$; ** $p<0.0$ I. ANOVA followed by Dunnett's post hoc test. Retrosplenial cortex (RSC), temporal cortex (TemC), dentate gyrus (DG), hippocampal regions (CAI and CA3).

significantly PAK-1 mRNA level in all studied cortical and hippocampal regions (Table 4). With increased dose of memantine, mRNA levels of RL/IF-1, GDI-1, and PAK-1 were also induced in other brain regions, and the effect was more pronounced. SHPS-1 mRNA levels were increased only after high doses of memantine (i.p.; $25-50 \mathrm{mg} / \mathrm{kg} ; 4 \mathrm{~h}$ ) (Table 4).

Peak induction of RL/IF-1 was observed in the cingulate and parietal cortices, and striatum $(\mathrm{CPu})$ at 1 and $4 \mathrm{~h}$ after administration of memantine (i.p.; $25 \mathrm{mg} / \mathrm{kg} ; 4 \mathrm{~h}$ ) (Figure 3). Furthermore, peak induction of SHPS-1 mRNA was observed in retrosplenial cortex at 4 and $8 \mathrm{~h}$ after memantine (i.p.; $25 \mathrm{mg} / \mathrm{kg} ; 4 \mathrm{~h}$ ) administration (data not shown). Other brain regions may also be regulated by acute MK-801 and memantine administration but were not quantitated.

\section{ISH Analysis of Candidate Genes of MK-801 Treatment}

From the microarray analysis, 34 candidate genes were identified of which nine were previously confirmed by the literature, and seven were confirmed by ISH with two false positives (Tables 2 and 3). Moreover, we confirmed the regulation of MK-801 selectively altered genes: FGF-2, 
Table 2 Profiling of Genes Altered by MK-80I Administration (i.p.; I mg/kg; $4 \mathrm{~h}$ ) in Rat Limbic Cortex

\begin{tabular}{llllll}
$\begin{array}{l}\text { Representative } \\
\text { gene name }\end{array}$ & GenBank\# & Swissprot\# & MK\#I & MK\#2 & Conf. \\
\hline Immediate early genes/oncogenes & & & & \\
c-fos & X06769 & PI284I & 1.79 & 1.71 & + + L \\
ear-3 & U10995 & Q6268I & 2.37 & 2.05 &
\end{tabular}

Transcription activators/repressors

$\begin{array}{lllll}\text { STAT-3 } & \times 91810 & \text { P52631 } & 0.63 & 0.66 \\ \text { RL/F-I I } & \times 63594 & \text { Q63746 } & 2.00 & 1.72+\end{array}$

Growth factors/receptors

$\begin{array}{lllllc}\text { FGF-2 } & \text { M22427 } & \text { PI3109 } & 1.70 & 1.55 & +; \mathrm{L} \\ \text { TrkB }^{\mathrm{a}} & \text { M5529I } & \text { Q63604 } & 1.83 & 1.82 & \mathrm{~L} \\ \text { P75NTR } & \text { X05I37 } & \text { P07I74 } & 2.45 & 2.20 & \\ \text { Activin type } & \text { S48190 } & \text { P38444 } & 2.00 & 2.01 & \\ \text { receptor } & & & & \end{array}$

Chaperones/heat shock proteins

HSP70 $\quad$ Z27II 8

GRP78 $^{\mathrm{a}} \quad$ MI4050

Q63718

P06761

2.00

2.43

2.06

1.85

Vesicle- and synaptic-related genes

$\begin{array}{ll}\text { GDI-I }^{\text {a }} & \text { U07952 } \\ \text { ARF-3 }^{\text {b }} & \text { LI2382 } \\ \text { NVP-2 }^{\text {a }} & \text { DI3I25 } \\ \text { Synaptotagmin 3 } & \text { D285I2 } \\ \text { Syntaxin-binding } & \text { U06069 } \\ \text { protein I } & \\ \text { Amphiphysin } & \text { Yl338I }\end{array}$

$\begin{array}{llll}\text { P50398 } & 1.90 & 1.67\end{array}$

PI6587

P35332

P40748

Q64320

1.96

1.72

0.64

0.38

1.95

1.65

2.06

008838

1.60

1.69

Neurotransmitter/hormone receptor

Dopamine 4 M84009

receptor

NMDAR2B $^{\mathrm{a}}$

M9I562

P30729

Q00960

Metabotropic

M92075

P3।42I

$\begin{array}{lll}1.60 & 1.83 & + \\ 1.66 & 1.89 & L \\ 2.16 & 2.47 & \end{array}$

receptor 2

G-protein-coupled receptors

$\begin{array}{ll}\begin{array}{l}\text { Neuromedin B } \\ \text { receptor }^{\mathrm{a}}\end{array} & \text { U37058 } \\ \text { Vasopressin V2 } & \text { ZII932 } \\ \text { receptor } \\ \begin{array}{l}\text { Thromboxane A2 } \\ \text { receptor }\end{array} & \text { D21I58 } \\ \begin{array}{l}\text { Prostaglandin E2 } \\ \text { receptor }\end{array} & \text { U94708 } \\ \begin{array}{l}\text { Somatostatin 2 } \\ \text { receptor }\end{array} & \text { M93273 } \\ & \end{array}$

$\begin{array}{llll}\text { P24053 } & 2.32 & 2.10 & + \\ \text { Q00788 } & 1.51 & 1.61 & \\ \text { P34978 } & 1.70 & 2.09 & \\ \text { Q62928 } & 0.45 & 0.22 & + \\ \text { P30936 } & 0.60 & 0.50 & \text { L }\end{array}$

\section{Neuropeptides}

$\begin{array}{ll}\text { NPYa }^{\mathrm{a}} & \text { M20373 } \\ \text { CRF }^{\mathrm{a}} & \text { M54987 }\end{array}$

Table 2 (Continued)

\begin{tabular}{|c|c|c|c|c|c|}
\hline $\begin{array}{l}\text { Representative } \\
\text { gene name }\end{array}$ & GenBank\# & Swissprot\# & МК\#I & MK\#2 & Conf. \\
\hline \multicolumn{6}{|c|}{ Osmotic balance regulators } \\
\hline $\mathrm{CCHB3}$ & M8875। & P54287 & 1.69 & 1.80 & \\
\hline $\begin{array}{l}\mathrm{Na}^{+} / \mathrm{K}^{+} \\
\text {transporting } \\
\text { ATPase } 2 \beta^{\mathrm{a}}\end{array}$ & j04629 & PI3638 & 2.04 & 1.93 & + \\
\hline $\begin{array}{l}\mathrm{Ca}^{2+} \text { transporting } \\
\text { ATPase-isoform } 2^{\mathrm{a}}\end{array}$ & j03754 & PII506 & 1.91 & 1.65 & \\
\hline \multicolumn{6}{|c|}{ Intracellular phosphatases } \\
\hline $\begin{array}{l}\text { Inositol } \\
\text { polyphosphate 4- } \\
\text { phosphatase II } \alpha\end{array}$ & U96920 & $A A B 72151$ & 0.63 & 0.56 & \\
\hline $\begin{array}{l}\text { Protein } \\
\text { phosphatase } 2 A^{a}\end{array}$ & M2359I & PII082 & 1.52 & 1.65 & \\
\hline LAR & LII586 & CAA5895 & 1.75 & 1.63 & \\
\hline \multicolumn{6}{|c|}{ Glucose metabolism and regulation } \\
\hline $\begin{array}{l}\text { Fructose- } \\
\text { biphosphate } \\
\text { aldolase A }\end{array}$ & MI2919 & P09।17 & 1.74 & 2.02 & L \\
\hline \multicolumn{6}{|l|}{ Miscelaneous group } \\
\hline $\begin{array}{l}\text { Neuronal } \\
\text { pentraxin receptor }\end{array}$ & AF005099 & O35764 & 2.08 & 2.60 & \\
\hline
\end{tabular}

Expression ratios shown represent the ratio obtained with each of the microarray duplicate and indicate normalized, non- $\log _{2}$-transformed ratios of MK-80 I - over saline-treated animals.

${ }^{a}$ Gene also regulated by memantine. Symbols for confirmation (Conf.): + , confirmation by ISH; -, false positive; L, confirmation by literature. P75NTR, low affinity neurotrophin receptor; HSP70, heat shock protein 70; GRP-78, $78 \mathrm{kDa}$ glucose regulated protein precursor; RL/F-I, regenerating liver inhibitory factor I; ARF3, ADP-ribosylation factor 3; trkB, tyrosine kinase receptor; GDI- I, GDPdissociation inhibitor I; NMDAR2B, N-methyl-D-aspartate receptor 2B subunit; NPY, neuropeptide Y; CCHB3, voltage-gated dihydropyridine-sensitive L-type calcium channel $\beta 3$ subunit; CRF, corticotropin-releasing factor; D4 receptor, dopamine D4 receptor; LAR, leukocyte common antigen-related tyrosine phosphatase; FGF-2, fibroblast growth factor 2; STAT-3, signal transducer and activator of transcription 3; NVP-2, neural visinin $\mathrm{Ca}^{2+}$-binding protein 2.

${ }^{\mathrm{b}} \mathrm{ARF3}$ gene was found to be upregulated on CDNA microarray, however, ISH revealed significant downregulation, with the peak reduction at $\mathrm{I}-4 \mathrm{~h}$ after MK801 treatment.

prostaglandin EP2 receptor, and dopamine D4 receptor. Additionally, one false negative was observed (HSP90 $\beta$ ). Quantification of these results can be found as supplemental material (http://www.uku.fi/aivi/supplementary_informa tion.htm).

Expression of RL/IF-1 was increased in retrosplenial and temporal cortices $(38 \pm 6.5 \%)$ as well as in hippocampal regions $(35 \pm 3.1 \%)$ (Figures $1 \mathrm{~d}$ and $2 \mathrm{~b})$. mRNA expression of GDI-1 was also increased in retrosplenial cortex $(33 \pm 5.9 \%)$ and CA3 hippocampal region $(15 \pm 5.3 \%)$ (Figures 1e and 2b). NVP-2 mRNA level was decreased in retrosplenial and temporal cortices $(85 \pm 2.5 \%)$. Moreover, an acute administration of MK-801 increased mRNA levels of the NVP-2 gene in hippocampal DG $(15 \pm 5.9 \%)$ (Figures If and $2 b$ ). 
Table 3 The Number of Genes Similarly and Differentially Regulated by Memantine and MK-80I in Rat Limbic Cortex by Microarray and ISH Analysis

\begin{tabular}{lrrr}
\hline $\begin{array}{l}\text { Altered gene } \\
\text { groups }\end{array}$ & $\begin{array}{c}\text { Mem gene } \\
\text { no. }\end{array}$ & $\begin{array}{c}\text { MK gene } \\
\text { no. }\end{array}$ & $\begin{array}{r}\text { Mem+MK } \\
\text { gene no. }\end{array}$ \\
\hline $\begin{array}{l}\text { Upregulated } \\
\text { All revealed genes }\end{array}$ & 24 & 29 & 12 \\
$\begin{array}{l}\text { Previously reported } \\
\text { a }\end{array}$ & 5 & 8 & 5 \\
$\begin{array}{l}\text { Not previously } \\
\text { reported }\end{array}$ & $19(8)$ & $21(5)$ & $7(4)$ \\
$\begin{array}{l}\text { Downregulated } \\
\begin{array}{l}\text { All revealed genes } \\
\text { Previously reported }\end{array}\end{array}$ & 4 & & \\
$\begin{array}{l}\text { Not previously } \\
\text { reported }\end{array}$ & $4(2)$ & 5 & 1 \\
\hline
\end{tabular}

Numbers of genes shown represent the results observed from two microarray experiments of each indicated treatment. The number in the parentheses represents the number of candidate genes confirmed by ISH.

${ }^{\mathrm{a}} \mathrm{Gene}$ previously reported in the literature to be regulated by NMDA antagonists. Memantine $25 \mathrm{mg} / \mathrm{kg}$ (Mem) and MK-80 I I mg/kg (MK).

\section{Study of GDI-1 Protein Induction}

Acute administration of memantine (i.p.; 10 and $25 \mathrm{mg} / \mathrm{kg}$; $8 \mathrm{~h}$ ) significantly increased protein levels of Rab/GDI-1 complex $(\sim 84 \mathrm{kDa})$ in the cytosolic fraction $(29 \pm 5.3 \%$; $64 \pm 6.8 \%$ ), and also in the membrane fraction of retrosplenial cortex $(33 \pm 4.2 \% ; 52 \pm 1.8 \%)$ (Figure 4). Cytosolic and membrane levels of free GDI-1 $(\sim 56 \mathrm{kDa})$ were unchanged after memantine administration.

\section{DISCUSSION}

Agents acting as noncompetitive antagonists of NMDA/ glutamate receptor induce the expression of several genes in limbic cortical regions, such as the cingulate, retrosplenial, and entorhinal cortices (Sharp et al, 1991; Gass et al, 1993; Tomitaka et al, 1996; Marvanová et al, 2001). In this study, we have applied expression profiling of MK-801 $(1 \mathrm{mg} / \mathrm{kg})$ and memantine $(5-50 \mathrm{mg} / \mathrm{kg})$ in the posterior cingulate and anterior retrosplenial cortices to look more carefully at induced genes, and to delineate molecular pharmacologic effects of NMDA/glutamate receptor antagonists in the brain.

We screened the expression of 1090 known rat genes representing about $2 \%$ of entire rat genome by using cDNA microarrays. We identified 13 genes regulated by both NMDA receptor antagonists of which 12 genes were upregulated and one was downregulated. In addition, 28 genes were regulated by memantine and 34 were regulated by MK- 801 administration. Confidence in the microarray results are supported by (1) identification of genes previously known to be altered by NMDA receptor antagonist treatment, (2) verification of novel regulated genes by ISH, and (3) verification by immunoblotting.

Antagonist of NMDA receptor subtype of glutamate receptor, protect against brain damage in neurological
Table 4 Memantine (M) (i.p.; 5-50 mg/kg; 4h) Dose Response of Gene Expression in Rat Brain Regions

\begin{tabular}{|c|c|c|c|c|c|}
\hline Gene & Region & M 5 mg/kg & M $10 \mathrm{mg} / \mathrm{kg}$ & M $25 \mathrm{mg} / \mathrm{kg}$ & $M 50 \mathrm{mg} / \mathrm{kg}$ \\
\hline \multirow[t]{5}{*}{ RL/F-I } & RSC & $117 \pm 8.7$ & $133 \pm 8.1 * * *$ & $142 \pm 3.2 * *$ & $170 \pm 9.5 * *$ \\
\hline & TemC & $96 \pm 9.5$ & $110 \pm 4.7$ & $|3| \pm 2.5 *$ & $|6| \pm 10 *$ \\
\hline & DG & $105 \pm 5.0$ & $106 \pm 7.5$ & $136 \pm 2.5^{* * *}$ & $|5| \pm 8.5 *$ \\
\hline & CAI & $105 \pm 7.8$ & $115 \pm 8.1$ & $|2| \pm 8.3^{*}$ & $134 \pm 5.3^{* * *}$ \\
\hline & CA3 & $105 \pm 7.8$ & $115 \pm 6.5$ & $|3| \pm 8.6 *$ & $160 \pm 11 *$ \\
\hline \multirow[t]{5}{*}{ GDI- I } & RSC & $115 \pm 8.1$ & $123 \pm 7.7 *$ & $125 \pm 4.4 *$ & $|3| \pm 5.3 * *$ \\
\hline & TemC & $10| \pm 1|$ & $94 \pm 8.6$ & $125 \pm 10 *$ & $133 \pm 12 *$ \\
\hline & DG & $122 \pm 10$ & $117 \pm 11$ & $114 \pm 17$ & $118 \pm 22$ \\
\hline & CAI & $119 \pm 8.0 *$ & $115 \pm 3.3^{*}$ & $128 \pm 9.5^{*}$ & $|4| \pm \mid 3^{*}$ \\
\hline & CA3 & $|2| \pm 3 . \mid$ **** & $128 \pm 5.8^{* * *}$ & $150 \pm 3.8^{*}$ & $162 \pm 8.5 * *$ \\
\hline \multirow[t]{5}{*}{ PAK-I } & RSC & $110 \pm 6.5$ & $116 \pm 3.2 *$ & $130 \pm 7.5^{*}$ & $133 \pm 8.2 *$ \\
\hline & TemC & $110 \pm 3.2$ & $117 \pm 3.7^{*}$ & $125 \pm 8.8^{*}$ & $|3| \pm 4.2 * * *$ \\
\hline & DG & $120 \pm 8.2 *$ & $130 \pm 8.9 * *$ & $134 \pm 1.8 * * *$ & $189 \pm 11 *$ \\
\hline & CAI & $115 \pm 6.5$ & $121 \pm 6.3^{*}$ & $132 \pm 8.5 *$ & $125 \pm 3.3 * * *$ \\
\hline & CA3 & $116 \pm 8.3$ & $119 \pm 3.2^{*}$ & $126 \pm 6.8 *$ & $143 \pm 3.3 * *$ \\
\hline \multirow[t]{5}{*}{ SHPS-I } & RSC & $|0| \pm 5.6$ & $110 \pm 8.1$ & $115 \pm 3.2 *$ & $125 \pm 3.8^{*}$ \\
\hline & TemC & $104 \pm 4.2$ & $105 \pm 3.2$ & $113 \pm 0.1 *$ & $|2| \pm 4.5^{*}$ \\
\hline & DG & $108 \pm 14$ & $112 \pm 8.4$ & $126 \pm 6.5^{*}$ & $147 \pm 7.6 *$ \\
\hline & CAI & $106 \pm 7.6$ & $107 \pm 6.7$ & $104 \pm 8.1$ & $111 \pm 6.5$ \\
\hline & CA3 & $107 \pm 9.0$ & $107 \pm 7.5$ & $110 \pm 4.9$ & $109 \pm 5.2$ \\
\hline
\end{tabular}

All values $( \pm$ SEM) are expressed as percentage of the saline-treated treatment period matched control sections ( $n=5-6$, ANOVA followed by Dunnett's post hoc test). ${ }^{*} p<0.05$; ${ }^{*} p<0.01$.

disorders (Danysz et al, 1995; Parsons et al, 1998; Krystal et al, 1999). However, in the previous studies it was observed that administration of NMDA receptor antagonists with high affinity or at high doses, can produce psychotomimetic effect in humans and neurotoxicity in specific neuronal subpopulations in the CNS of rodents, in particular neurons of the limbic cortex. Injured neurons in layers III and IV of the posterior cingulate and anterior retrosplenial cortex are characterized by abnormal cytoplasmic vacuoles (Olney et al, 1989; Sharp et al, 1991). At a $1 \mathrm{mg} / \mathrm{kg}$ dose of MK-801, this vacuole formation is reversible and not detected after $24 \mathrm{~h}$ (Olney et al, 1989). Therefore, it is likely that not only genes related to beneficial effects of MK- 801 and memantine treatments, but also genes related to neurotoxic or stress-response effects of cortical cells are revealed in this study. In this study, we observed increases in mRNA levels of c-fos and HSP70 in the retrosplenial and cingulate cortex of adult rat treated with $25 \mathrm{mg} / \mathrm{kg}$ memantine and $1 \mathrm{mg} / \mathrm{kg}$ MK- 801 . Moreover, we observed increased transcriptional production of FGF-2 after MK-801 treatment.

Genes coding for a diverse range of proteins whose function is related to secretion, synaptic vesicle trafficking, and regulation of membrane trafficking were shown to be upregulated by different NMDA receptor antagonist treatments. GDI-1 (RabGDI, GDI- $\alpha$ ) transcript level was 
a

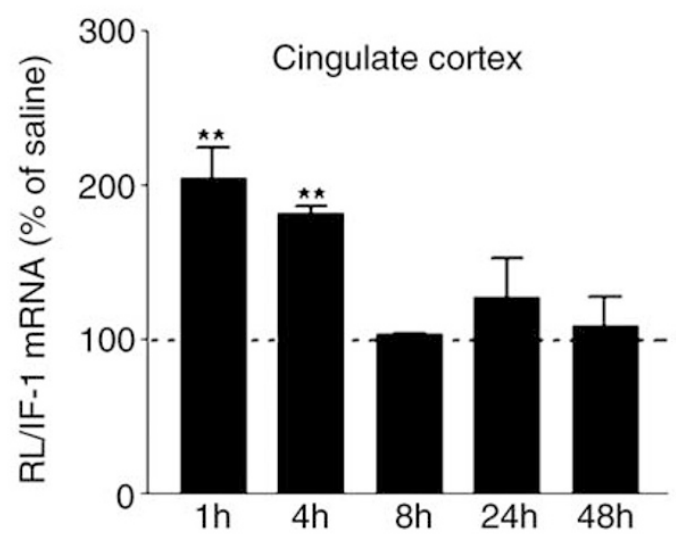

b

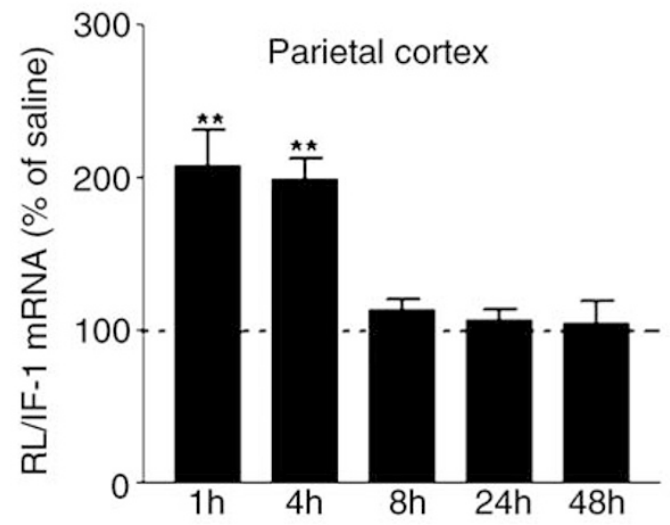

C

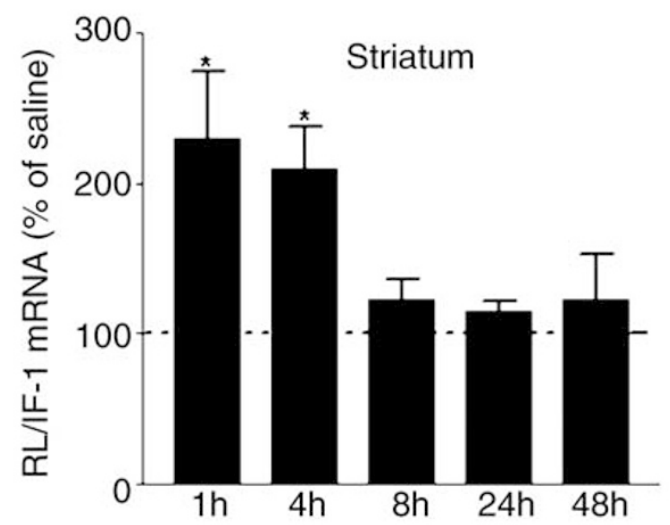

Figure 3 The time course of memantine effect on RL/F-I mRNA expression. The rats were i.p. injected either with saline and killed after $4 \mathrm{~h}$ or with memantine $(25 \mathrm{mg} / \mathrm{kg})$ and killed I, 4, 8, 24, or $48 \mathrm{~h}$ later. Optical densities were quantified by MCID/M4-analysis system from cingulate cortex (a), parietal cortex (b), and striatum (c) for RL/IF-I gene. Values are expressed as percentage of saline (mean \pm SEM from three rats in each treatment group). Significant differences between saline and memantine treated rats are indicated: * $p<0.05$; ${ }^{*} p<0.01$, ANOVA, Dunnett's post hoc test.

increased by both NMDA receptor antagonists. The lowest dose of memantine increased GDI-1 mRNA levels in the hippocampal subfields, CA1 and CA3, and also in the cortex after higher doses. Moreover, we observed significantly increased levels of Rab/GDI-1 protein complex in membrane and cytosolic fractions of rat retrosplenial cortices.
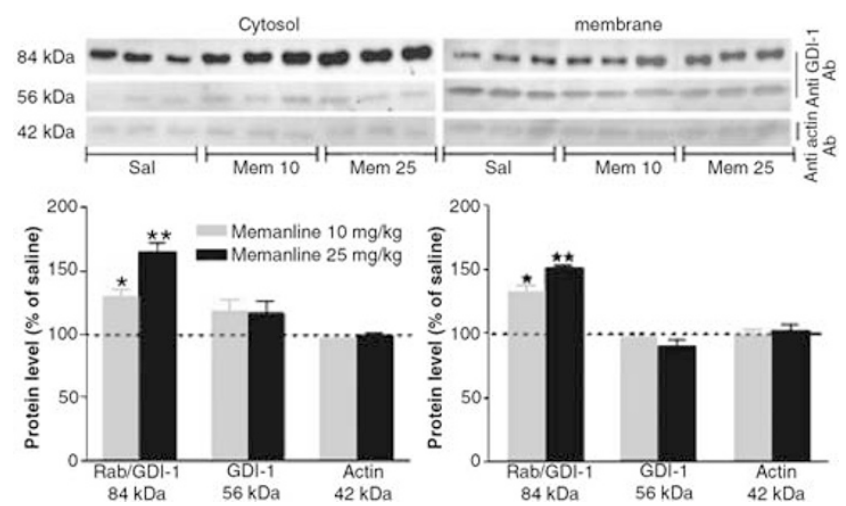

Figure 4 Western blot analysis of GDI protein expression in retrosplenial cortex after memantine treatment. The rats were injected with memantine (i.p.; 10 or $25 \mathrm{mg} / \mathrm{kg}$ ) for an $8 \mathrm{~h}$ time period, and protein from the dissected retrosplenial cortex was obtained from cytosolic and membrane fractions. Proteins were run on SDS/polyacrylamide gels and transferred to nitrocellulose filters. The filters were probed either with antiGDI-I or anti-actin antibodies. Values are expressed as percentage of saline. Data shown are mean \pm SEM from three rats. $* p<0.05$; $* * 2<0.0$ I, significantly different compared to saline-treated rats (ANOVA, Dunnett's post hoc test)

However, since GDI-1 interacts with most Rab proteins of which approximately 40 have been identified, we were unable to determine the specific Rab protein(s) involved in this process. The production of GDI-1 protein is critical for vesicular membrane transport in both the endocytic and also exocytic pathways via regulation of Ras-like GTPases of the Rab family proteins (Pfeffer et al, 1995; Martinez and Goud, 1998; Luan et al, 1999; Seabra et al, 2002). Moreover, GDI-1 has an important role in vivo to suppress hyperexcitability of the CA1 pyramidal neurons, which changes the firing properties of the neurons (Ishizaki et al, 2000).

Consistent with previous reports demonstrating that MK801 and memantine stimulate hypothalamic-puituitaryadrenal activity by activating corticotropin-releasing factor or cortocoliberin (CRF) in the hypothalamus (Lee et al, 1994; Zhou et al, 1998), we found the increased transcript levels of CRF after both treatments. Neuropeptide Y (NPY) and neuromedin $\mathrm{B}$ receptor were also upregulated by both treatments, whereas somatostatin receptor 2 was downregulated after MK-801. Taken together, these results suggest effects on multiple neuropeptide systems.

Memantine and MK-801 elicited also induction of the immediate early gene RL/IF-1 in several brain regions. The RL/IF-1 gene is the rat homolog of human MAD-3, and possesses I- $\kappa \mathrm{B}$ activity of broad specificity and thus it is able to inhibit the binding of p50-p60 NF- $\kappa \mathrm{B}, \mathrm{c}-$ Rel-p50, and RelB-p50, but not homodimeric NF- $\kappa \mathrm{B}$ to the $\kappa \mathrm{B}$ site (Tewari et al, 1992). NF- $\kappa \mathrm{B}$ is a ubiquitous transcription factor that regulates transcription of multiple genes involved in immune and inflammatory responses (Baeuerle and Henkel, 1994). Previous studies have reported that inappropriate regulation of NF- $\kappa \mathrm{B} /$ Rel-mediated transcription is associated with pathological conditions including acute inflammatory responses, toxic/septic shock, acute phase reactions, atherosclerosis, radiation damage, and also with several neuropathologies (Grilli et al, 1993; Baldwin, 1996; O’Neill and Kaltschmidt, 1997). In post-mortem tissue from patients with neurodegenerative disease or cultured 
neurons exposed to neurotoxic stimuli, increased NF- $\kappa \mathrm{B}$ activity in cells has been reported (Kaltschmidt et al, 1995; Terai et al, 1996; Hunot et al, 1997). Furthermore, several studies have demonstrated that stimulation of both NMDA and non-NMDA glutamate receptors strongly stimulate $\mathrm{NF}-\kappa \mathrm{B}$ in vitro (Guerrini et al, 1995; Kaltschmidt et al, 1995). Additionally, another gene involved in immune and inflammatory responses, prostaglandin EP2 receptor (Narumiya et al, 1999), was downregulated.

This study revealed several new regulated transcripts in the brain after acute memantine or MK-801 treatment. While a $25 \mathrm{mg} / \mathrm{kg}$ dose of memantine causes more general expression changes in RL/IF-1 and GDI-1 transcripts, as shown by representative autoradiograms, regional changes were observed only at lower doses of memantine. These findings suggest caution in over extrapolation of gene expression changes, especially in cases like RL/IF-1 and GDI-1, where the ISH expression pattern is diffuse and regional differences may be subtle and revealed only by lower doses. Moreover, these changes were observed and reported only after acute administration. In a clinical setting of $\mathrm{AD}$ treatment, memantine is used chronically in relatively low doses. The $25 \mathrm{mg} / \mathrm{kg}$ dose results in plasma levels reaching $\sim 6.5 \mu \mathrm{M}$ concentration that are still specific to NMDA receptor antagonism, although it is approximately seven times higher than the typical therapeutic values $(\sim 1 \mu \mathrm{M})$ (Kornhuber et al, 1994). The current study was designed to identify early effects of memantine treatment and potential new drug targets for NMDA receptor antagonists. Thus, future studies in a rat model should use chronic administration of lower memantine doses $(1-5 \mathrm{mg} / \mathrm{kg})$ to mimic the clinical regimen, and in this way reveal gene candidates responsible for its beneficial therapeutical effect. Moreover, as the rat genome project advances toward completion, whole genome expression array analysis could eventually be possible to perform.

In summary, we have used microarrays to study differentially expressed genes in response to acute treatments of high and modest affinity NMDA receptor antagonists. This study identified new genes not previously implicated in the molecular pharmacologic actions of high affinity and medium affinity NMDA receptor channel blockers, MK-801 and memantine, in the brain. Some caution should be taken in extrapolation of our results since only a portion of the microarray results were confirmed by independent methods. Nonetheless, genes regulated by a clinically relevant dose of memantine might be important for its therapeutic effects, and could potentially constitute new targets for investigation. Further and more detailed characterization of these gene relationships to neural function may lead to a better understanding of neurodegenerative processes and ultimately their treatment.

\section{ACKNOWLEDGEMENTS}

We thank Drs Antero Salminen and Outi Kontkanen for helpful discussions and critical comments. We are also grateful to Markus Storvik for his support in animal experiments. We are indebted to Dr Jarno Laitinen for providing GTP, and Dr G Quack at Merz + Pharmaceuticals,
Frankfurt/Main, Germany for endowment of Memantine $\times \mathrm{HCl}$. This study has been supported by the Academy of Finland.

\section{REFERENCES}

Baeuerle PA, Henkel T (1994). Function and activation of NFkappa B in the immune system. Annu Rev Immunol 12: 141-179.

Baldwin Jr AS (1996). The NF-kappa B and I kappa B proteins: new discoveries and insights. Annu Rev Immunol 14: 649-683.

Choi DW (1988). Glutamate neurotoxicity and diseases of the nervous system. Neuron 1: 623-634.

Danysz W, Parsons CG, Bresink I, Quack G (1995). Glutamate in CNS disorders. Drug News Perspect 8: 261-277.

Foster AC, Wong EH (1987). The novel anticonvulsant MK-801 binds to the activated state of the $N$-methyl-D-aspartate receptor in rat brain. Br J Pharmacol 91: 403-409.

Gass P, Herdegen T, Bravo R, Kiessling M (1993). Induction and suppression of immediate early genes in specific rat brain regions by the non-competitive $N$-methyl-D-aspartate receptor antagonist MK-801. Neuroscience 53: 749-758.

Gill R, Brazell C, Woodruff GN, Kemp JA (1991). The neuroprotective action of dizocilpine (MK-801) in the rat middle cerebral artery occlusion model of focal ischaemia. $\mathrm{Br} J$ Pharmacol 103: 2030-2036.

Görtelmeyer R, Erbler H (1992). Memantine in the treatment of mild to moderate dementia syndrome. A double-blind placebocontrolled study. Arzneimittelforschung 42: 904-913.

Grilli M, Chiu JJ, Lenardo MJ (1993). NF-kappa B and Rel: participants in a multiform transcriptional regulatory system. Int Rev Cytol 143: 1-62.

Grunblatt E, Mandel S, Maor G, Youdim MB (2001). Gene expression analysis in $N$-methyl-4-phenyl-1,2,3,6-tetrahydropyridine mice model of Parkinson's disease using cDNA microarray: effect of R-apomorphine. J Neurochem 78: 1-12.

Guerrini L, Blasi F, Denis-Donini S (1995). Synaptic activation of NF-kappa B by glutamate in cerebellar granule neurons in vitro. Proc Natl Acad Sci USA 92: 9077-9081.

Huettner JE, Bean BP (1988). Block of N-methyl-D-aspartateactivated current by the anticonvulsant MK-801: selective binding to open channels. Proc Natl Acad Sci USA 85: 1307-1311.

Hunot S, Brugg B, Ricard D, Michel PP, Muriel MP, Ruberg M et al (1997). Nuclear translocation of NF-kappaB is increased in dopaminergic neurons of patients with Parkinson disease. Proc Natl Acad Sci USA 94: 7531-7536.

Ishizaki H, Miyoshi J, Kamiya H, Togawa A, Tanaka M, Sasaki T et al (2000). Role of rab GDP dissociation inhibitor alpha in regulating plasticity of hippocampal neurotransmission. Proc Natl Acad Sci USA 97: 11587-11592.

Kaltschmidt C, Kaltschmidt B, Baeuerle PA (1995). Stimulation of ionotropic glutamate receptors activates transcription factor NF-kappa B in primary neurons. Proc Natl Acad Sci USA 92: 9618-9622.

Kilpatrick GJ, Tilbrook G (2002). Memantine Merz. Curr Opin Invest Drugs 3: 798-806.

Kornhuber J, Bormann J, Hubers M, Rusche K, Riederer P (1991). Effects of the 1-amino-adamantanes at the MK-801-binding site of the NMDA-receptor-gated ion channel: a human postmortem brain study. Eur J Pharmacol 206: 297-300.

Kornhuber J, Weller M, Schoppmeyer K, Riederer P (1994). Amantadine and memantine are NMDA receptor antagonists with neuroprotective properties. J Neural Transm 43(Suppl): 91-104.

Krystal JH, D'Souza DC, Petrakis IL, Belger A, Berman RM, Charney DS et al (1999). NMDA agonists and antagonists as probes of glutamatergic dysfunction and pharmacotherapies in neuropsychiatric disorders. Harv Rev Psychiatry 7: 125-143. 
Lee S, Rivier C, Torres G (1994). Induction of c-fos and CRF mRNA by MK-801 in the parvocellular paraventricular nucleus of the rat hypothalamus. Brain Res Mol Brain Res 24: 192-198.

Luan P, Balch WE, Emr SD, Burd CG (1999). Molecular dissection of guanine nucleotide dissociation inhibitor function in vivo. Rab-independent binding to membranes and role of Rab recycling factors. J Biol Chem 274: 14806-14817.

Martinez O, Goud B (1998). Rab proteins. Biochim Biophys Acta 1404: 101-112.

Marvanová M, Lakso M, Pirhonen J, Nawa H, Wong G, Castrén E (2001). The neuroprotective agent memantine induces brainderived neurotrophic factor and trkB receptor expression in rat brain. Mol Cell Neurosci 18: 247-258.

Massieu L, Thedinga KH, McVey M, Fagg GE (1993). A comparative analysis of the neuroprotective properties of competitive and uncompetitive $\mathrm{N}$-methyl-D-aspartate receptor antagonists in vivo: implications for the process of excitotoxic degeneration and its therapy. Neuroscience 55: 883-892.

Meldrum B (1986). Excitatory amino acid antagonists as novel anticonvulsants. Adv Exp Med Biol 203: 321-329.

Mirnics K, Middleton FA, Marquez A, Lewis DA, Levitt P (2000). Molecular characterization of schizophrenia viewed by microarray analysis of gene expression in prefrontal cortex. Neuron 28: 53-67.

Muller WE, Mutschler E, Riederer P (1995). Noncompetitive NMDA receptor antagonists with fast open-channel blocking kinetics and strong voltage-dependency as potential therapeutic agents for Alzheimer's dementia. Pharmacopsychiatry 28: $113-124$.

Narumiya S, Sugimoto Y, Ushikubi F (1999). Prostanoid receptors: structures, properties, and functions. Physiol Rev 79: 1193-1226.

Olney JW, Labruyere J, Price MT (1989). Pathological changes induced in cerebrocortical neurons by phencyclidine and related drugs. Science 16: 1360-1362.

O’Neill LA, Kaltschmidt C (1997). NF-kappa B: a crucial transcription factor for glial and neuronal cell function. Trends Neurosci 20: 252-258.

Parsons CG, Danysz W, Quack G (1998). Glutamate in CNS disorders as a target for drug development: an update. Drug News Perspect 11: 523-569.

Parsons CG, Danysz W, Quack G (1999). Memantine is a clinically well tolerated $N$-methyl-D-aspartate (NMDA) receptor antagonist- a review of preclinical data. Neuropharmacology 38: 735-767.

Parsons CG, Gruner R, Rozental J, Millar J, Lodge D (1993). Patch clamp studies on the kinetics and selectivity of $N$-methyl-Daspartate receptor antagonism by memantine (1-amino-3,5dimethyladamantan). Neuropharmacology 32: 1337-1350.
Paxinos G, Watson C (1986). The Rat Brain in Stereotaxic Coordinates. Academic Press: Sydney.

Pfeffer SR, Dirac-Svejstrup AB, Soldati T (1995). Rab GDP dissociation inhibitor: putting rab GTPases in the right place. J Biol Chem 270: 17057-17059.

Schena M, Shalon D, Davis RW, Brown PO (1995). Quantitative monitoring of gene expression patterns with a complementary DNA microarray. Science 270: 467-470.

Seabra MC, Mules EH, Hume AN (2002). Rab GTPases, intracellular traffic and disease. Trends Mol Med 8: 23-30.

Sharp FR, Jasper P, Hall J, Noble L, Sagar SM (1991). MK-801 and ketamine induce heat shock protein HSP72 in injured neurons in posterior cingulate and retrosplenial cortex. Ann Neurol 30: 801-809.

Skolnick P (1999). Antidepressants for the new millennium. Eur J Pharmacol 375: 31-40.

Terai K, Matsuo A, McGeer PL (1996). Enhancement of immunoreactivity for NF-kappa B in the hippocampal formation and cerebral cortex of Alzheimer's disease. Brain Res 735: $159-168$

Tewari M, Dobrzanski P, Mohn KL, Cressman DE, Hsu JC, Bravo R et al (1992). Rapid induction in regenerating liver of RL/IF-1 (an I kappa B that inhibits NF-kappa B, RelB-p50, and c-Rel-p50) and PHF, a novel kappa B site-binding complex. Mol Cell Biol 12: 2898-2908.

Tomitaka S, Hashimoto K, Narita N, Sakamoto A, Minabe Y, Tamura A (1996). Memantine induces heat shock protein HSP70 in the posterior cingulate cortex, retrosplenial cortex and dentate gyrus of rat brain. Brain Res 18: 1-5.

Ueda A, Hamadeh HK, Webb HK, Yamamoto Y, Sueyoshi T, Afshari CA et al (2002). Diverse roles of the nuclear orphan receptor CAR in regulating hepatic genes in response to Phenobarbital. Mol Pharmacol 61: 1-6.

Wenk GL, Danysz W, Mobley SL (1994). Investigations of neurotoxicity and neuroprotection within the nucleus basalis of the rat. Brain Res 655: 7-11.

Winblad B, Mobius HJ, Stoffler A (2002). Glutamate receptors as a target for Alzheimer's disease-are clinical results supporting the hope?. J Neural Transm 62(Suppl): 217-225.

Wong EH, Kemp JA, Priestley T, Knight AR, Woodruff GN, Iversen LL (1986). The anticonvulsant MK-801 is a potent $\mathrm{N}$-methyl-D-aspartate antagonist. Proc Natl Acad Sci USA 83: 7104-7108.

Zhou Y, Yuferov VP, Spangler R, Maggos CE, Ho A, Kreek MJ (1998). Effects of memantine alone and with acute 'binge' cocaine on hypothalamic-pituitary-adrenal activity in the rat. Eur J Pharmacol 3: 65-71. 